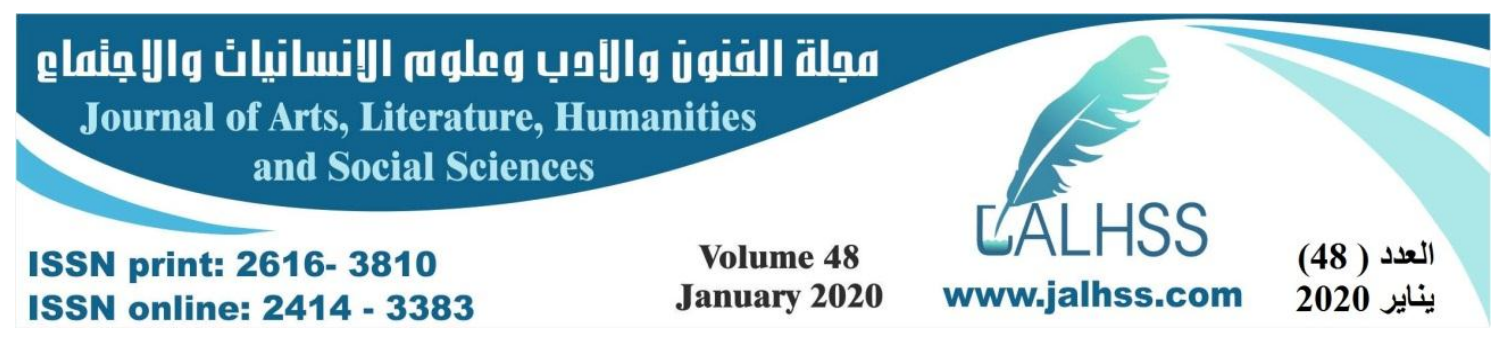

\title{
The Effectiveness of European Social Charter and Inter-American Human Rights Systems: Enforcement Mechanisms and Obstacles
}

\section{(An Analytical Study)}

\author{
Amanj Ali Qadir \\ Assistant Lecturer, College of Law - Salahaddin University-Erbil- Iraq \\ Email: amanj.qadir@su.edu.krd
}

\begin{abstract}
Regional human rights systems, consisting of regional instruments and mechanisms, play an important role in the promotion and protection of human rights. Regional human rights instruments such as treaties, conventions and declarations; help to localise international human rights norms and standards, reflecting the particular human rights concerns of the region. Regional human rights mechanisms for instance commissions, special rapporteurs and courts; then help to implement these instruments on the ground. Despite, adopting many human rights conventions and treaties as well as establishing several human rights committees and organizations, still more to be done and there is desperate need for effective regional human rights system that promote and protect human rights and prevent grave braches of human rights in the regional level. To this end, the European countries formed the Council of Europe while, in the American continent the Organization of American States (OAS) was established. One of the most important aims of the Council of Europe and the OAS is the protection of human rights by addressing international human rights norms and standards on the targeted region. Consequently, several conventions and instruments have been adopted in Europe and American continents, such as the European Social Charter, the Revised Charter, the European Convention of Human Rights, the American Declaration of the Rights and Duties of Man and the American Convention of Human Rights. This research will address the effectiveness of the regional human rights in particular the European Social Charter and Inter-American Human Rights Systems in protecting and promoting human rights by evaluating their enforcement mechanisms and standards. Each system will be assessed and evaluated as well as addressing their obstacles and challenges.
\end{abstract}

Keywords: International law, Regional Human Rights System, European Social Charter, Inter-American Human Rights System, the American Convention of Human Rights. 


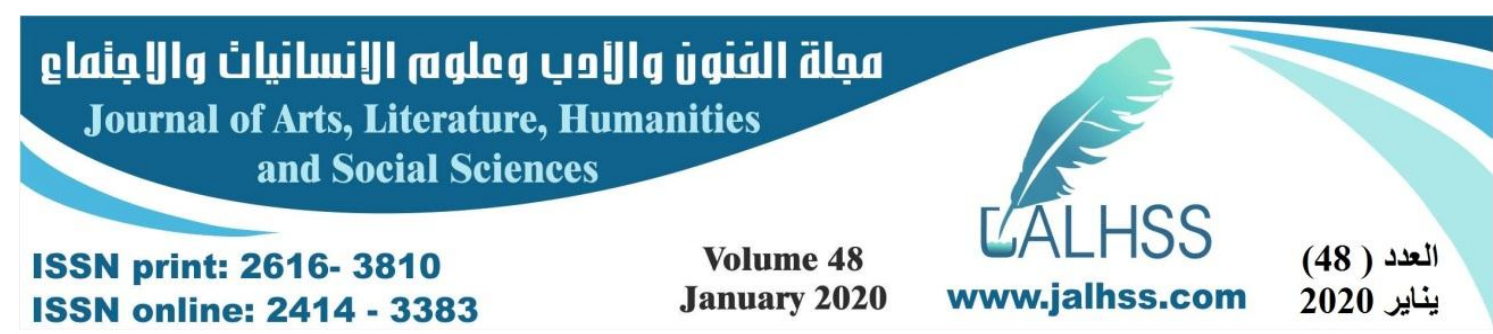

\section{Introduction}

Despite the fact that International Law provides wide range of protection for human rights by adopting many human rights conventions and treaties as well as establishing several human rights committees and organizations, still more to be done and there is desperate need for effective regional human rights system in order to promote and protect human rights and prevent grave braches of human rights in the regional level. Therefore, the existence of an effective regional human rights system is of fundamental importance to the promotion and protection of human rights. Accordingly, the European countries addressed the idea of a United Europe. Similarly, in the American continent the Organization of American States (OAS) was established in 1948. One of the most important aims of the Council of Europe and the OAS is the protection of human rights. Accordingly, they adopted several conventions and instruments, such as the European Social Charter, the Revised Charter, the European Convention of Human Rights, the American Declaration of the Rights and Duties of Man and the American Convention of Human Rights. In their provisions, the regional human rights conventions recognize that their substantive provisions are influenced, inspired by the content of the Universal Declaration of Human Rights and the wording of the preamble and the body of the Charter of the United Nations, and other international human rights instruments. In other words, regional human rights instruments such as treaties, conventions and declarations; help to localise international human rights norms and standards, reflecting the particular human rights concerns of the region. Regional human rights mechanisms help to implement these instruments on the ground.

\section{The aim and importance of the research}

Unlike International Human Rights system, there are relatively few published studies about Regional Human Rights system and their role in protecting Human Rights. The aim of this research lies in addressing the effectiveness of the regional human rights in particular the European Social Charter and Inter-American Human Rights Systems in protecting and promoting human rights along with evaluating their enforcement mechanisms that entail such protection. As well as addressing the obstacles and challenges of each system.

\section{Research Problem}

Despite the fact that International Law provides wide range of protection for human rights by adopting many human rights conventions and treaties as well as establishing several human rights committees and organizations, still more need to be done and there is desperate need of effective regional human rights system that promote and protect human rights and prevent grave braches of human rights in the regional level. Does these regional human rights systems are effective in terms of protecting human rights? Are they adequate Human Rights instrument? This research will try to address above questions. 


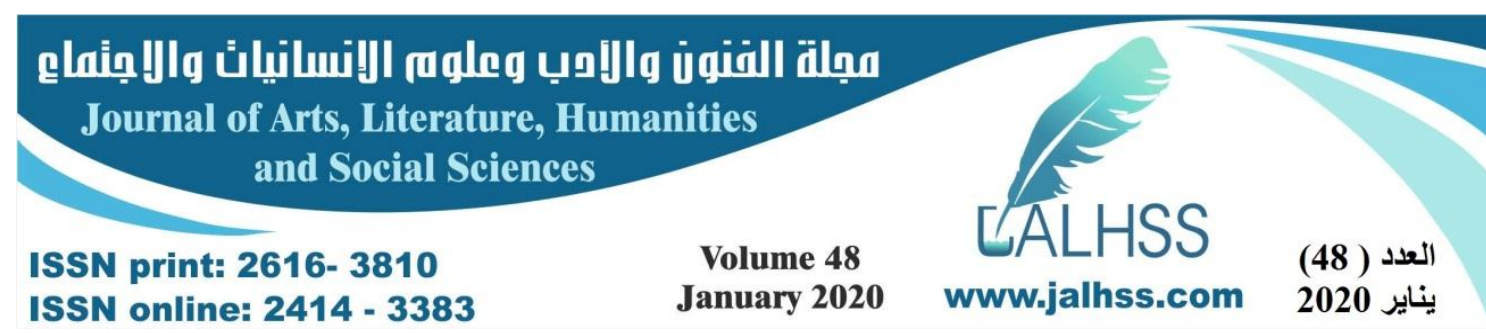

\section{Research Mythology}

In this research, the analytical method is adopted by analysing the text of the conventions and charters that established regional Human Rights systems and organisations. However, evaluating the enforcement mechanisms of each system as well as their obstacles.

\section{Scope of the Research}

The research is covering both the European Social Charter and Inter-American Human Rights Systems by focussing on their effectiveness in protecting Human Rights and considering their standard mechanisms and their challenges.

\section{Plan of the Research}

The research is divided into two parts. First part is allocated for the European Social Charter System and the second for the Inter-American System. Once a brief background of each system is given, their enforcement mechanisms are examined in detail. In addition, each system is evaluated and the main obstacles and weaknesses that impede the effectiveness of these systems are examined.

\section{Part I}

\section{European Human Rights System}

There are two instruments administering human rights in Europe, the European Convention of Human Rights, which is beyond the scope of this research, and the European Social Charter.

\subsection{European Social Charter}

The European Social Charter (ESC) was adopted by the Council of Europe in October 1961, but entered into force in February 1965. The purpose of adopting the charter was to generally protect human rights in Europe and particularly shield Western Europe against communist ideology. As the civil and political rights were protected by the European Convention of Human Rights, the economic and social rights of the European countries needed protection as well. After the adoption of the Convention, the Committee of Ministers formed after recommendation of the consultative Assembly of Council of Europe, suggested that a common policy in the social field should be adopted. In May 1954, the Committee of Ministers established the Social Committee in order to adopt the European Social Charter. Then, in 1958, the Social Committee prepared a draft of the Charter which was consisted of two parts. Part I contained the policy objectives of economic and social rights, which had to be ratified by state parties. Part II included the obligations of the parties. This draft was examined and some amendments were suggested by a Conference in 1958, during which representatives of state parties and international organizations participated. Finally, after years of hard work, the Social Committee was able to draft the final text, 


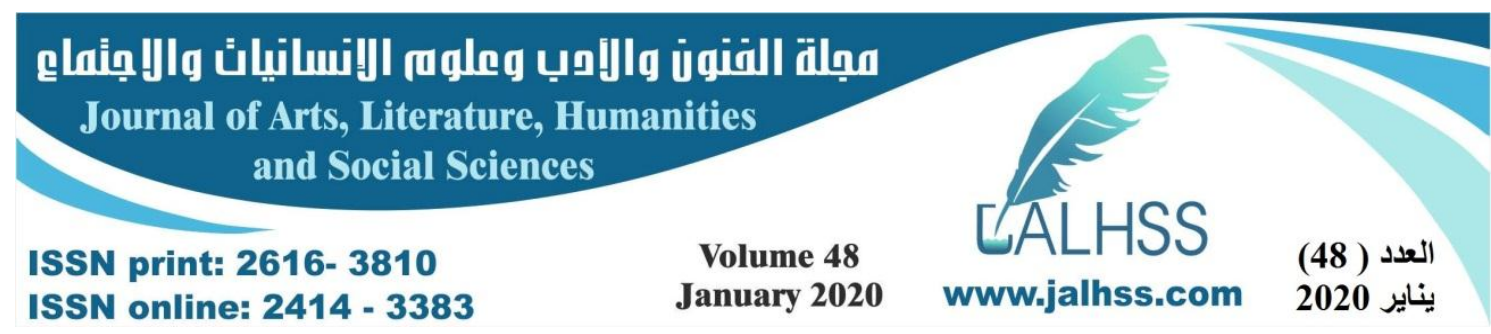

which was adopted by the Committee of Ministers in September 1961(Harris and Darcy, 2001, P6)

Although there was additional protocol to the charter in 1988, the revitalization process aimed at giving breath to the Charter began in the 1990s. The "Committee Charter-Re" was established for this reason. The need for revision of the substantive guarantees and the insufficiency of the protected rights led to the entire revision of the Charter. Therefore, in May 1996, the Revised Charter was adopted and came into force in 1999 as (De Schutter, 2010, P14).

\subsection{Enforcement Mechanisms}

The European Social Charter, like the other treaties regarding human rights, has its own mechanism and supervision system to implement its provisions and observe the member states' compliance with the Charter. The supervision system includes state reporting and collective complaints according to (Churchill and Khaliq, 2004, P417). Before looking at the supervision system, it is preferred to briefly consider the supervisory bodies.

\section{A. The European Committee of Social Rights (ECSR)}

(Pérez, 2006, 425) believes that it was originally known as the Committee of Independent Experts and was consist of nine members. Following a decision of the Committee of Ministers, the number increased to fifteen. They are elected for six years term, with the possibility to be re-elected. They are nominated by state parties and must be experts in the national and international social field. The committee examines the states' reports in terms of whether the national law and state practice are in accordance with the Charter. It also assesses the admissibility of submitted complaints.

\section{B. The Governmental Committee}

It consists of representatives of state parties and states can nominate and change their representatives. International organization of employers and international trade unions' organisations are also invited to participate in the works and meetings of the Governmental committee by sending their representatives to its meetings as observers. According to article 27(2) of the Charter, the observers are entitled to receive documentations and have their opinion and observations on the report of the Committee. Based on the decision of the ECSR and states' reports, the Governmental Committee determines the situations that require recommendation and submits its report to the Committee of Ministers to take further action. Accordingly, it facilitates and prepares the decisions for the Committee of Ministers (Harris and Darcy, 2001, P301).

\section{The Committee of Ministers}

It composes of the Ministers of Foreign Affairs of the state parties to the Council of Europe. It is the most important supervisory and observatory body of the Charter. In 


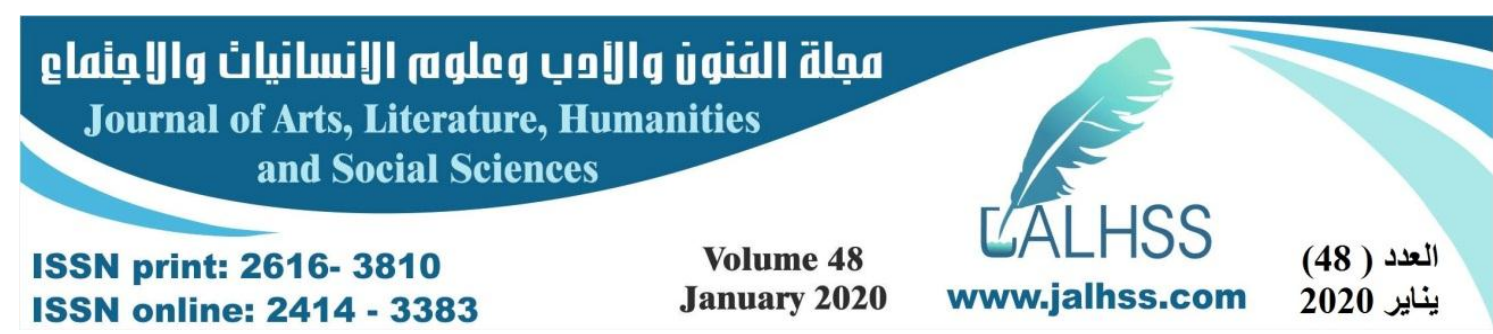

the light of the assessment reports of the ECSR on the periodical repots of state parties and collective complaints mechanisms, the Committee of Ministers makes recommendations to the state party concerned if it finds that the state has not applied the provisions of the Charter sufficiently. Furthermore, the committee may adopt resolutions to end the procedure if the state has not violated its obligations under the ESC (Pérez, 2006, 426). After briefly considering the supervisory bodies, we will address the supervision system includes state reporting and collective complaints.

\subsubsection{State Report (National Report)}

States may accept only a specific number of articles in part II of the 1961 Charter and the 1996 Revised Charter. They must bind themselves by at least six out of the nine so called 'hard core' articles which are: article 1 (right to work), article 5(right to organise), article 6 (collective bargaining), article 7 (right of children and young persons to protection), article 12 (right to social security), article 13 (right to social and medical assistance), article 16 (right of the family to social, legal and economic protection), article 19 (right of migrant workers and their families to protection and assistance) and article 20 (right of equal opportunities and equal treatment in matter of employment and occupation without discrimination on the grounds of sex) under the Revised Charter. States also must consider themselves bound by a number of articles or paragraphs of part II of the Charter which are no less than sixteen articles or sixty three paragraphs. Accordingly, in order to be a state party, it is not necessary to accept the entire provisions of the Charter. The state parties are obliged to submit periodical reports to the European Committee of Social Rights (ECSR) determining the application of the provisions of the Charter in their law and practices (De Schutter, 2010, P26). There are two types of periodical reports, reports on the accepted and on the non-accepted provisions.

\section{A. Reports on Accepted Provisions}

Originally, under article 21 of the Charter, states shall submit biennial reports on all of the provisions that they have accepted. The gradual raise in the number of state parties led to the increase of the workload of the supervisory bodies. Therefore, in 1992 the Committee of Ministers decided that only for a trail and specific period of time, contracting parties should report the 'hard core' articles every two years, while 'non hard core' articles shall be reported every four years. This new system was confirmed in 1996 and applied in the fourteenth reporting cycle. The new reporting system was criticised that it delays the reporting period of the states and that this is not of their benefit, as they need to be reminded of their obligations more frequently. In addition, in case of defer of the decision by ECSR, this period may be even doubled. Another weakness found was that the reports must be submitted in one of the two official languages of the Council of Europe, which is not only difficult and time consuming for the state to prepare it, but also difficult for the observing body to follow (Harris and Darcy, 2001, P307). 


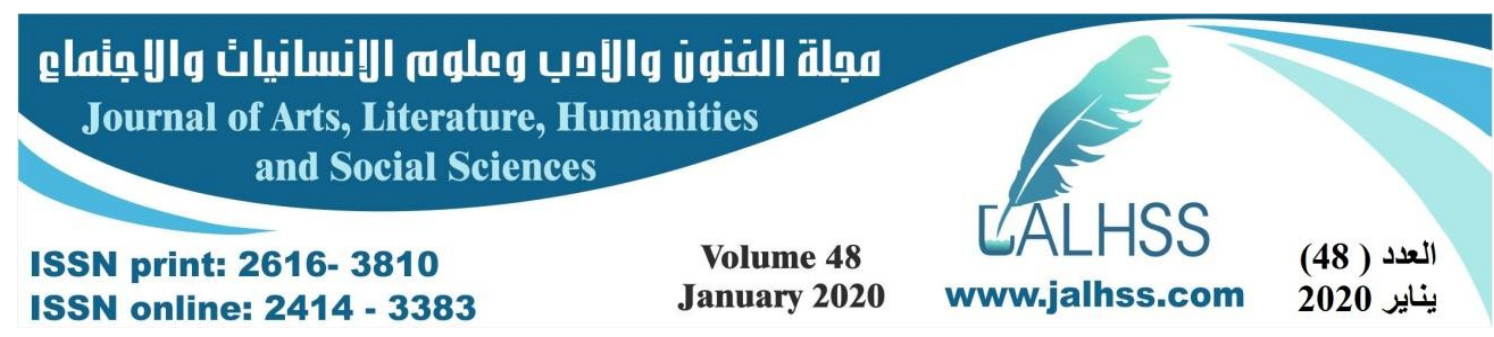

\section{B. Reports on Non-accepted Provisions}

According to (Harris and Darcy, 2001, P314) under article 22 of the Charter, the Committee of Ministers requires state parties to submit reports on the provisions that they have not accepted from the part II of the charter. The Committee of Ministers requests such reports based on the suggestion of the Governmental Committee. The implementation of article 22 took long time, that the procedure did not start until 1978 and then only a small number of reports have been submitted. The reports were mainly focused on certain provisions that have been accepted by a limited number of contracting parties or those provisions which were relevant to the development of social rights in Europe as (De Schutter, 2010, P21) points out. Accordingly, not all of the non-accepted provisions were reported. The ECSR in 1989 stated that article 22 should be applied on all the non-accepted provisions, a view that was shared by also the Governmental Committee. However, this has not been done and there are many non-accepted provisions that have not been reported yet. Despite the importance of the article 22, it has not encouraged the state parties to accept more provisions of the Charter (Harris and Darcy, 2001, P315).

\section{The Examination of the Reports}

Under article 23(1) of the Charter, states shall send a copy of the report to the national organizations that are associated to the international employers and international trade unions. These organizations may have comments on the reports and their comments should be sent to the Secretary General of the Council of Europe. Furthermore, according to the protocol 1991, the reports shall be forwarded to the nongovernmental organisations which have a consultative status within the Council of Europe (Pérez, 2006, 427). The European Committee of Social Rights shall examine the reports of a state party and decide whether the situation in that state is in accordance with the Charter. The Committee shall send its conclusion to the Governmental Committee. In turn, the Governmental Committee must prepare a report to the Committee of Ministers and shall identify the situation that needs specific intention. Then, based on that report, the Committee of Ministers shall make recommendations to the state concerned and require the situation to be changed in compliance to the Charter as states by (Shelton, 2010, P96). However, the Committee rarely adopts recommendations it mostly issues resolutions.

\subsubsection{Collective Complaints}

As stated by (Harris and Darcy, 2001, P354) in the past, the national reports were the only enforcement mechanism of implementing the European Social Charter. Nowadays, as a result of the revitalization of the Charter, the Collective Complaints Protocol (CCP) has been adopted in 1995 and entered into force in 1998. According to (Cullen,2009, P61) the protocol introduced the system of collective complaints that meant to be the completion of the reporting system. According to article 1 of the 1995 protocol, certain number of organisations can make complaints against states for their violation of the Charter, such as international organisations of employers and trade 


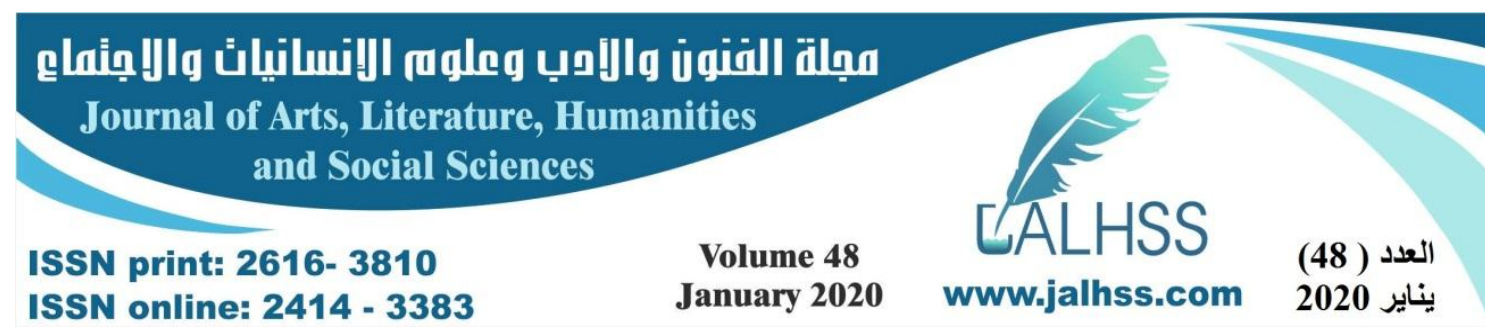

unions, and other international non-governmental organisations with a consultative status with the European Council. Moreover, national representative organisations of employers and trade unions within the jurisdiction of a particular state may lodge complaints. In addition, under article 2 of the $\mathrm{CCP}$, national non-governmental organisations can also lodge complaints against the state within which they operate, but only when that state declares and admits this right to them. Among the state parties to the CCP, only Finland has made such declaration and no national organisation has lodged complaints against Finland yet.

In terms of the procedure of the examination of complaints, any of the organisations mentioned above may submit complaints against certain state to the Secretary General. The Secretary informs the state concerned and sends the complaints to the European Committee of Social Rights in order to be examined. After receiving the complaint, the Committee has to decide whether it is admissible or not. There are some criteria which have to be met in order a complaint to be considered admissible. It must be lodged by a competent organisation in accordance with article 1 and 2 of the CCP. Regarding the national organisations, the Committee must check whether the organisation which has submitted the complaint is representative of organisations of employers and trade unions (Harris and Darcy, 2001, P362). Furthermore, under article 4 of the CCP, the complaint must be submitted in writing. Moreover, it must be on the provisions of the Charter and must show in what respect the state party has failed to apply the provision.

As (De Schutter, 2010, P21) points out that the system is based on the collective complaints basis, the individual complaints are not allowed and exhaustion of domestic remedies is not required. If the complaint is admissible, the state concerned and the complainant are invited to submit their comments on the matter. The ECSR may ask for an oral hearing of the view of the parties, if needed. Then, after reaching to a decision and concluding the report, the ECSR must send it to the Committee of Ministers. This decision is made public as soon as the Committee of Ministers recommends a resolution; or no more than four months after it. It would seem that the publication of the decisions may put pressure on the state to comply with the decision. However, if the report of the ECSR found that the state violated the Charter, the Committee of Ministers under article 9(1) of the CCP shall adopt a recommendation to that state by two-thirds of voting. The state subjected to the recommendation must provide information in its next national report on the measures that it has taken to implement the recommendation. In practice, the Committee adopts resolutions rather than recommendations.

\subsection{Evaluation of the system}

Based on the aforementioned mechanisms and procedures, the European Social Charter system has several structural and procedural weaknesses that challenge its effectiveness. To begin with, the system is slow in its procedures, because it involves several supervisory bodies as mentioned above. Each of these bodies has its own views and makes comments on the report it receives, as a result prevent the swift 


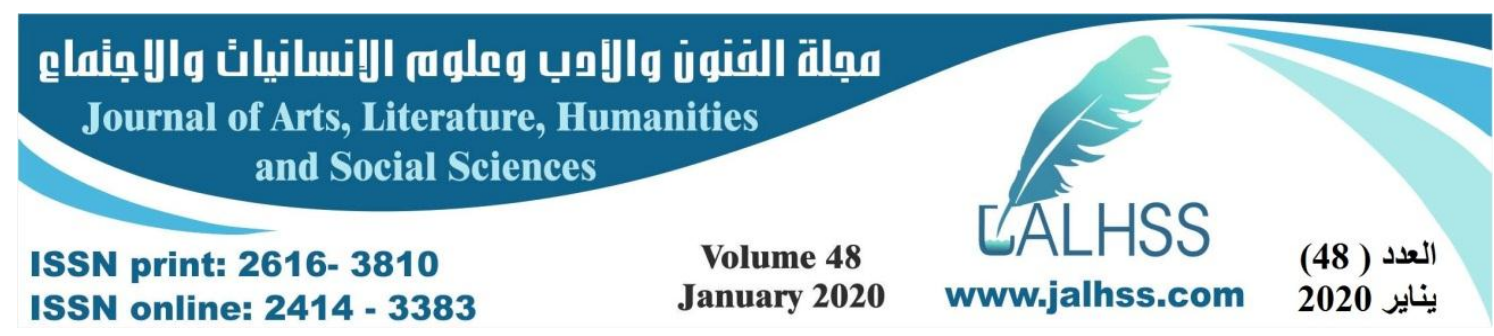

response of the system (Vandamme, 1994, P633). Another weakness is the relation between the ECSR and the Governmental Committee that has not been clearly defined. There is an overlap in their functions, as the Governmental Committee not only makes comments on the national reports and the reports of the ECSR, but also may have different views and concerns than those of the ECSR. It is therefore argued that having two bodies operating in the same area and having the same competences, but working in different ways has weakened the supervisory system according to (Schmidt, 1992, 659). Moreover, states have failed to change the human rights situation in their respective countries in order to be in compliance with the Charter. Therefore, (Barillat, 2005, P32) believes that the main challenge is to find ways of encouraging and persuading states to take effective actions and necessary changes towards the enforcement of their obligations, since the Charter is silent with regard to measures that the Committee of Ministers should adopt to enforce its recommendations when states continue to violate their obligations.

Furthermore, (Briggs, 2007) indicates that sometimes states in their reports do not provide sufficient information. Therefore, the ECSR is forced to defer its conclusion and require more clarification from the reporting state. The same process may be repeated again in the upcoming report, if the state fails once again to provide the required information this may cause time consuming and consequently delay in taking needful actions. Moreover, (Vandamme, 1994, P635) believes that the decision of the ECSR is not binding but declaratory and cannot decide remedies and compensations. For instance, it requested the Committee of Ministers to contribute in the costs of complainants, such as in European Roma Rights Centre (ERRC) v Greece and Confederation Francaise de L'encadrement CFE-CGC v France, but the Committee refused to do so. Finally, as (Cullen,2009, P63) states that the social partners have inadequate role in the supervisory system, especially the national organisations. They do not have consultative status and cannot sent observations to the meetings of the Governmental Committee, as the International Organizations of employers and workers do. It could be said that the weakness of the supervisory mechanism of the charter affects the effectiveness of the European Human Right system, because if the enforcement mechanism is insufficient, then the states' compliance with the instruments would be inadequate. It is doubtful to have a strong and effective instrument without having a proper and sufficient enforcement mechanism.

According to (Schmidt, 1992, 661) there are, however, other obstacles that affect the effectiveness of the European Social Charter system. The main obstacle is that politics play a significant role in the system throughout the Council of Europe's political bodies. For instance, the Governmental Committee determines which NGOs are entitled to have consultative status within the Council of Europe. In addition, the Committee of Ministers as a political body has the final word in the supervision system by adopting recommendations. Although the Committee has obligation under article (28) 1 of the Revised Charter to adopt recommendations, it rarely does so. This might be due to the complicated voting system that requires the majority of two-thirds of votes, which is difficult to be achieved because of the political interests of state 


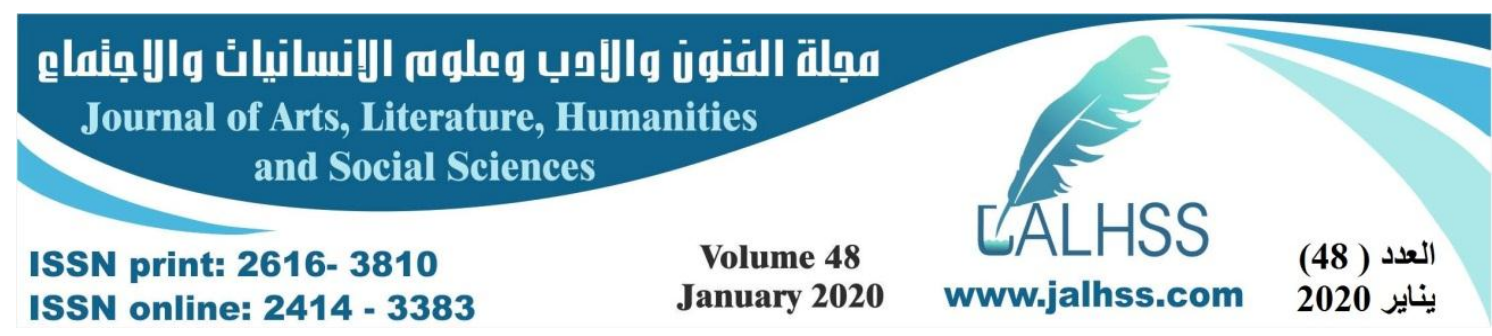

parties. Therefore its political nature prevents it from addressing individual recommendations to the state concerned. For example, the Committee for more than 20 years has not adopted any recommendation to states in terms of article 21, even though other supervisory bodies advised it to do so.

Another obstacle is that states have the options to choose not to accept all the provisions of the both Charter and Revised Charter. They can only accept specific and certain provisions, the so called 'hard core'. The division of articles to 'hard core' and 'non hard core' does not necessarily mean that the former are more important than the later. For instance, article 4 of the Charter which is about the right to fair remuneration that provides for a decent standard of living, although it is an important right, but it is considered as 'non hard core'(Harris and Darcy, 2001, P363). It seems therefore, that there are many other important rights that remain unreported by states, because they are either not accepted by states or considered as 'non hard core' article.

\section{Inter-American Human Rights system}

\section{Part II}

Similarly to the European system, the Inter-American human right system has two main instruments, the American Declaration of the Rights and Duties of Man and the American Convention of Human Rights.

\section{A. The American Declaration of the Rights and Duties of Man}

The Inter-American Conference on problems of War and Peace held in Mexico 1945, required the Inter-American Juridical Committee to prepare a draft declaration on the rights of man. After four years of hard work and debates on the binding status and after preparing more than one draft, the final draft was submitted to the ninth International Conference of American States in 1948 and was adopted as a nonlegally binding treaty. Accordingly, the Inter-American system had a declaration on human rights before the adoption of the Universal Declaration of Human Rights by the United Nations. It contains not only civil, political, economic and social rights, but also duties on individuals, such as the duty to vote and obey the laws (Steiner, Alston and Goodman, 2007, P1021).

\section{B. The American Convention of Human Rights}

The idea of the Convention dates back to 1959 in the fifth meeting of Consultative of Ministries of foreign affairs in Chile, where decided on preparation to adopt the human rights convention. The Inter-American Council of Jurist and the Commission prepared a draft and submitted it to the Organisation of American States (OAS). It was then adopted in 1969 by the Inter-American Specialized Conference on Human Rights in San José, Costa Rica and entered into force in 1978. Unlike other American countries, the USA has not ratified the convention 


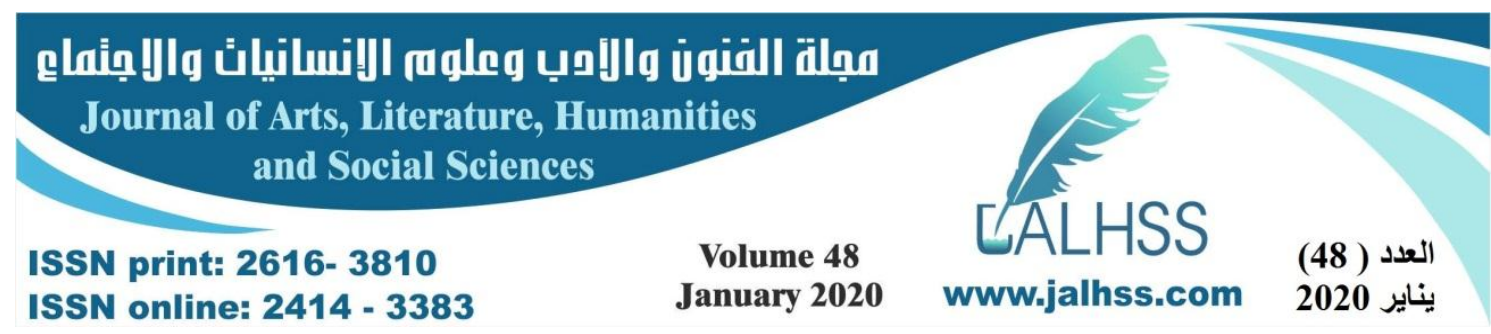

yet. It contains a broad range of rights and freedoms, but mainly civil and political rights (The Inter-American, 2003, P15).

\subsection{The Enforcement Mechanisms}

There are two institutions that their mandate is to promote and protect human rights, while administering the implementation of human rights according to the InterAmerican Human Rights system; the Inter-American Commission on Human Rights and the Inter-American Court of Human Rights.

\subsubsection{The Inter-American Commission on Human Rights}

The Inter-American Commission on Human Rights was adopted in the fifth meeting of the Consultation of the Secretariat of Foreign Affairs in 1959 in Chile and entered into force in 1960, after its statutes' approved by the council of the OAS. According to article 18 of its statute, the Commission has the following functions: First, arising awareness of human rights among American states. Second, making recommendations to states in order to adopt progressive measures. Third, preparing and requesting reports on human rights situations from governments. Fourth, playing an advisory role for OAS in terms of human rights (Rescia and Seitles, 2006, P593) In 1965, the second Special Inter-American Conference in Rio de Janeiro, Brazil decided to amend the statute of the Commission in order to give more functions and authority to accomplish its purpose. The Commission amended its statute and became able to examine the individual petitions and adopt recommendations to the state concerned. If the State failed to comply with the recommendations and has accepted the contentious jurisdiction of the Court, the Commission may submit the matter to the Court which issue orders to the State concerned (The Inter-American, 2003, P16). The Commission gained dual role when the Inter-American Convention entered into force in 1978. Its first function was to work as an organ of the OAS to promote human rights in the state parties to the OAS. Its second function was to become an organ of the Convention and monitor human rights in the contracting parties to the Convention ( Rescia and Seitles, 2006, P593). The Commission follows two procedures under the Convention; the complaints procedure and the reporting procedure, which are briefly discussed below.

\section{A. Complaints Procedure}

There are two types of complaints, interstate complaints and individual complaints. In terms of interstate complaints, according to article 45 of the Convention, only states who recognise the competence of the Commission to receive complaints can lodge complaints before the Commission. In addition, there are other criteria that should be met, for example, the domestic remedies must be exhausted and the complaints must be submitted within six months of the final judgment in accordance with article 46. If the complaint deemed admissible, the Commission requires friendly settlement. If a friendly settlement cannot be achieved, then the Commission adopts recommendation. 


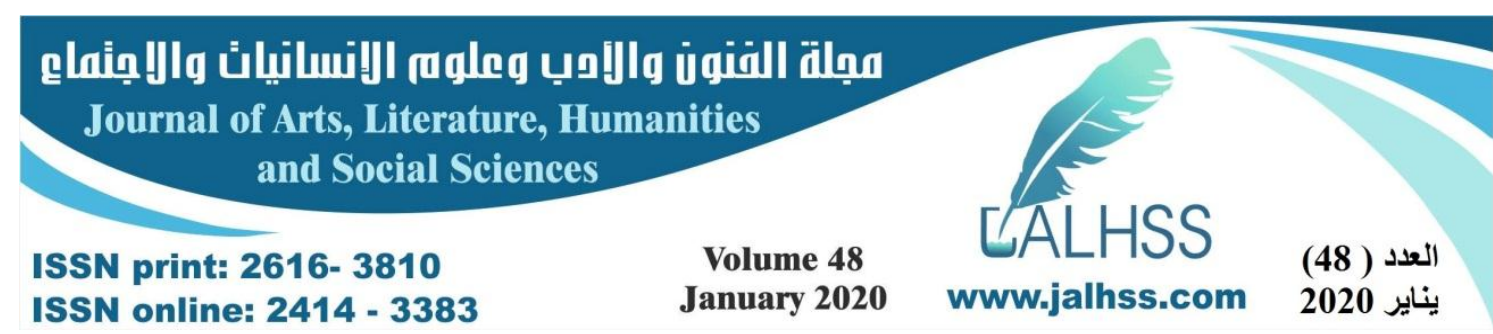

The only complaint that has been brought before the Commission was the complaint of Nicaragua .v Costa Rica, but the Commission held that the complaint was inadmissible.

With regard to individual complaints, As (Osterhaus, 2014, P3) points out in case of violation of rights protected in the Inter-American Declaration or in the InterAmerican Convention, under article 44 of the Convention any person or group of persons or non-governmental entity may lodge petitions against states. Certain requirement must be met in order for a complaint to be examined by the Commission under article 46 of the Convention. First, the commission may request information from the parties and undertake on-site visiting. Second, the commission seeks a friendly settlement. Third, it adopts recommendations to the state concerned if a friendly settlement is not achieved. However, if the recommendations were not complied with by the state concerned, the Commission resorts to judicial procedure and refers the case to the Inter-American Court.

\section{B. Reporting Procedure}

The Commission is able to prepare reports with regard to the human rights situation in the state parties and submit them to the OAS under article 41 of the Convention. It also prepares reports on specific countries based on the on-site visit. The purpose of these reports is to update the OAS with information about human rights in those countries. The best example of such report is the report on human rights in Argentina about so called "The Dirty War" in 1978, where more than 15,000 people were disappeared and 5,000 more have been murdered by the state. .Nowadays, the site visiting procedure has fade away and instead, a commissioner carries out the visit and presents the situation in a press release at the end of his visit (Steiner, Alston and Goodman, 2007, P1039).

\subsubsection{The Inter-American Court of Human Rights}

The Court is an autonomous judicial institution established in 1979. It consists of seven members elected by the OAS General Assembly. The Court has contentious and advisory jurisdiction. According to article 61 of the Convention, only the Commission on Human Right and states that recognise the jurisdiction of the Court can submit cases to it (Rodríguez-Pinzón and Martin,2006,P58). Furthermore, the court must be satisfied that the domestic remedy ha exhausted and the Commission's procedure of has completed and recommended to refer the case to the court, then the Court will examine the case (Shaver, 2010, P620). The court may decide whether the state violated its obligation and in case of violation, the court can decide on remedy that the injured party shall be compensated. The court's decision is final and binding for both parties. With regard to the advisory jurisdiction, under article 64, the court can interpret the Convention or any other international human rights' instrument. Thus, the state parties to the Convention and the OAS state members can request advisory opinion from the Court. Moreover, states may consult the Court in terms of 


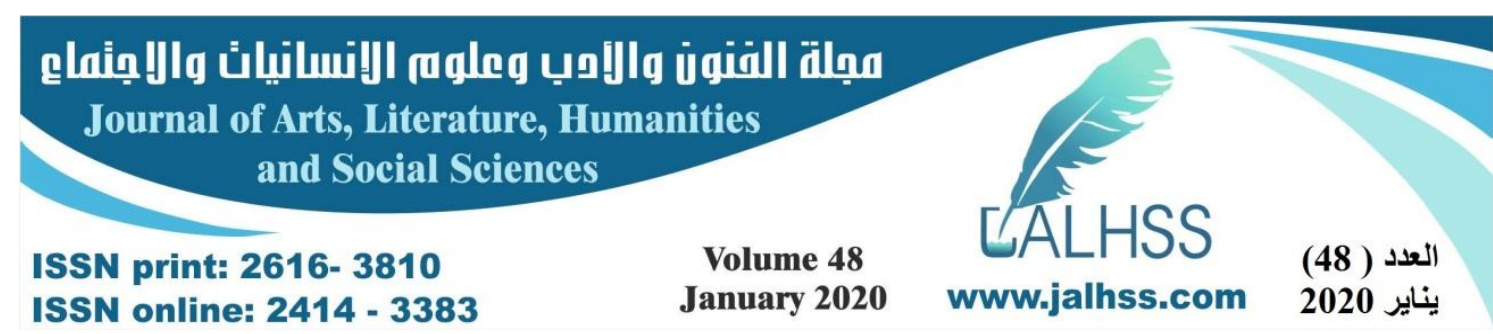

the compatibility of their legislation with the Convention (Rodríguez-Pinzón and Martin, 2006, P59).

\subsection{Evaluation of the System}

As discussed above, the two supervisory bodies have been in charge of the implementation of the Inter-American human right instruments and they have played a great role in promoting and protecting human rights in the American continent. However, there have been challenges that affected their functions. The main challenge is the ability of those bodies to enforce their decisions. Since the states' compliance with the decisions of the supervisory bodies is basically based on the good willing of the states, therefore in case of states' regression of their obligations those bodies cannot do much. For example, after being criticised for preventing due process, Peru withdrew its recognition of the Court (Grossman, 2000, P16). More importantly, in case of non-compliance with the decision of the Court, the Court informs the OAS General Assembly for further action. Since the convention is silent about the power of the General Assembly to take actions, it may recourse to political action in order to put pressure on the state to comply with the decisions (Steiner, Alston and Goodman, 2007, P1026). In addition, the system is slow in addressing cases. The requirement of exhausting domestic remedies and the Commission's procedures which may take years, have led to $\mathrm{c}$ in combating human rights violations. When a case is referred to the Court, it may take a couple of years to be resolved. Accordingly, the parties to the case may become victims of the slowness of the system. This could be solved by providing sources to the supervisory bodies to function as permanent institutions and by scheduling regular meetings.

According to (Rescia and Seitles, 2006, P593) there are, however major obstacles that impede the effectiveness of the system. One of such is the small number of ratified countries. There is large number of states that have not ratified the Convention and not even recognise the contentious jurisdiction of the Court, such as the United States, Canada and the Caribbean countries. Therefore, there are some who argue that the system is Latin American and not Inter-American. This means that the Court's supervision function is not applied to all American counties. It is considered as a disadvantage for the citizens of non-state parties that cannot access the Court even through the Commission. As (Shaver, 2010, P639) states that another obstacle is the inadequate human and financial resources that make it difficult for the supervisory bodies to fulfil their functions. For instance, in 2005, the Commission only examined eighty four complaints out of 1,330. Furthermore, states' failure to implement their obligations under the human rights instruments and comply with the decisions of the enforcement bodies has affected the overall function of the system (Goldman, 2009,P 856). 


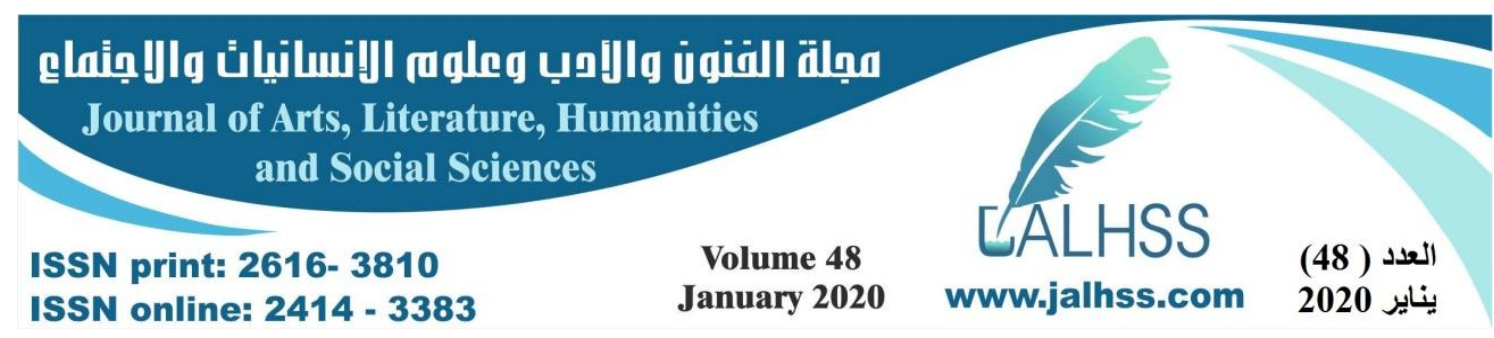

\section{Conclusion}

The research has examined The Effectiveness of European Social Charter and InterAmerican Human Rights Systems considering Enforcement Mechanisms and Obstacles as well as addressing each system's supervisory bodies. It can be concluded that these systems can become much more effective and competent in safeguarding and promoting human rights by overcoming the weaknesses and obstacles discussed in this research. The research has reached below results and recommendations:

\section{A. Results}

1. The Regional human rights bodies have played an important role in promoting and protecting human rights throughout the globe, especially the European and the Inter-American human rights system. Although these systems are well equipped and highly advanced, they have several structural and procedural weaknesses that affect their functions and challenge their effectiveness.

2. This research has discussed the key challenges that the European and the InterAmerican human rights systems face. One of such challenges is the enforcement mechanisms. In case of non-compliance, when a state is violating its obligations under these instruments or systems there is no much to do.

3. In terms the European Charter, it can only address recommendation which is not legally binding. With regard to the Inter-American, when a state refuse to comply with the decision of the Court, it refers the situation to the General Assembly. Since there is no clear guidance for the Assembly to take further action, it resorts to political pressure in order to enforce the state concerned to comply with the courts decisions.

4. The lack or insufficiency of financial and even personnel resources is the main obstacle that impede the effectiveness of both systems.

\section{B. Recommendations}

1. The supervisory bodies shall be limited since having several supervisory bodies may render the swift action of the mentioned systems.

2. The role and function of each supervisory body shall be clearly defined to prevent the overlap between them while performing their functions.

3. The ECSR decisions must be binding rather than declaratory to make states to comply with their obligations under the charter. Having said that this may need to amend the charter and insert necessary changes in this regard.

4. European Human Rights System, since the local social partners and national organisations are more aware of the human rights situations on the ground, they shall be given adequate role in the supervisory system; by granting them consultative status and accepting their representative as observations in the meetings of the Governmental Committee, as their counterparts of International Organizations of employers and workers do.

5. States shall be encouraged to ratify the Convention of American Human Rights and more importantly to accept the Jurisdiction of the Inter-American 


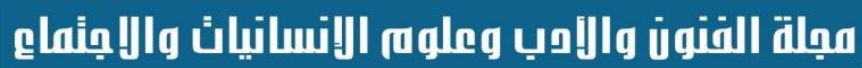

Journal of Arts, Literature, Humanities

and Social Sciences

ISSN print: 2616- 3810

Volume 48

ISSN online: $2414-3383$

Court of Human Rights by organising conferences and roundtable meetings since are only small number of American countries ratified the conversion.

6. More financial and human resources shall be provided to tackle unjustified delays and slowness of the system in addressing the Human Rights issues.

7. Politics is playing significant role in which undermines the effectiveness of the system, therefore its role shall be decreased by providing legal means of pressure on states to comply with the Human Rights convention and standards. 


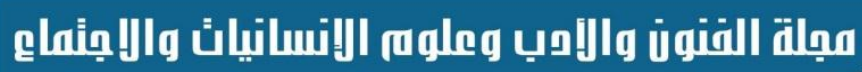

Journal of Arts, Literature, Humanities

and Social Sciences

ISSN print: 2616- 3810

Volume 48

ISSN online: 2414 - 3383

January 2020

\section{References}

1. Barillat, R. (2005). The Supervisory Machinery of the European Social Charter: Recent Developments and their Impact in de Búrca \& de Witte (eds), Social Rights in Europe (OUP).

2. Briggs, A. T. (n.d) 'The Revised European Social Charter' Retrieved March 9, 2017 from http://www.wcl.american.edu/hrbrief/07/2briggs.pdf .

3. Churchill, R.R \& Khaliq, U. (2004) . The Collective Complaints System of the European Social Charter: An Effective Mechanism for Ensuring Compliance with the Economic and Social Rights?. European Journal of International Law, 15(3), 417.

4. Cullen, H. (2009). The Collective Complaints System of the European Social Charter: Interpretative Methods of the European Committee of Social Rights. Human Rights Law Review, 9(1), 61.

5. De Schutter, O. (2010). The Two Lives of the European Social Charter' in De Schutter. The European Social Charter: A Social Constitution for Europe (Bruylant)

6. Dinah, L. S. (2010). Regional Protection of Human Rights (OUP).

7. Goldman, R. K. (2009). History and Action: The Inter-American Human Rights System and the Role of the Inter-American commission on Human Rights. Human Rights Quarterly, 31 (4), 856.

8. Grossman, C. (2000) . Moving Toward Improved Human Rights Enforcement in the America. Human Rights, (27), 16.

9. Harris, D \& Darcy, J. (2001). The European Social Charter. NY: Transnational Publishers.

10. Osterhaus, J. (2014) . Annex to the ABC of Human Rights for Development Cooperation: The Inter-American Human Rights System (The Inter-American System). Retrieved March 13, 2017 from http://www.institut-fuermenschenrechte.de/uploads/tx_commerce/e-info-

tool the abc of hr_for_dev_coop the interamerican_system.pdf .

11. Pérez, J. B. (2006). The European Social Charter' in Felipe Gómez Isa and Koen de Feyter. International Protection of Human Rights: achievements and Challenges, Bilbao: University of Deusto.

12. Rescia, V. R. \& Seitles, M. D. (2000). The Development of the Inter-American Human Rigts System: A Historical Prospective and a Modern-Day Critique' New York Law School Journal of Human Rights. (16), 593.

13. Rodríguez-Pinzón, D \& Martin, C. (2006). The Prohibition of Torture and Illtreatment in the Inter-American Human Rights System: A Hand Book for Victims and their Advocates. Retrieved March 14, 2017 from http://www.omct.org/files/2006/11/3977/handbook2_full_eng.pdf .

14. Schmidt, M. G. (1992). A Fresh Impetus for the European Social Charter. International and Comparative Law Quarterly, (41), 659.

15. Shaver, L . (2010). The Inter-American Human Rights System: An Effective Institution for Regional Rights Protection. Washington University Global Studies Law Review. 9 (4), 62. 


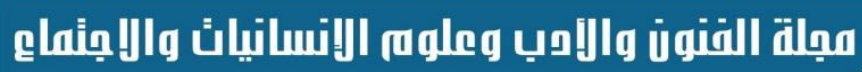

Journal of Arts, Literature, Humanities

and Social Sciences

ISSN print: 2616- 3810

Volume 48

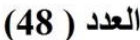

ISSN online: 2414 - 3383

January 2020

www.jalhss.com

يناير 2020

16. Steiner, H., Alston, P. \& Goodman, R. (2007) . International Human Rights in Context: Law, Politics, Morals. ( $3^{\text {rd }}$ edition). OUP).

17. The Inter-American. (N,.D). Basic Documents Pertaining to Human Rights in the Inter-American System. Retrieved March 13, 2017 from http://www.corteidh.or.cr/docs/libros/Basing101.pdf .

18. Vandamme, F. (1994). The revision of the European Social Charter. International Labour Review, (133), 633. 